\title{
Public HEALTH AND PRIVATE LIVES
}

\author{
MARGARET BRAZIER * AND JOHN HARRIS* *
}

\section{INTRODUCTION}

The fundamental principle, plain and incontestable, is that every person's body is inviolate.'

The common law of England has consistently affirmed a doctrine of bodily integrity which makes no distinction between degrees of violence ${ }^{2}$ and prohibits unauthorised touchings. The evolution of the laws of assault and battery into a coherent legal doctrine affirming and protecting patient autonomy in medical treatment is nonetheless of relatively recent origin and remains flawed in its detail. The adoption in Sidaway v. Board of Governors of Bethlem Royal Hospital and the Maudsley Hospital ${ }^{3}$ of the professional standard to govern information disclosure deprives patients on occasion of the information crucial to a maximally autonomous choice.

However, two principles are now crystal clear. First, any treatment involving physical contact with a competent adult must be expressly authorised by her. If a health professional acts without consent (save in emergency), or exceeds the consent given by the patient, he commits a civil battery and a criminal assault. ${ }^{4}$ It is no defence that he proves that he acted in what he believed to be the patient's best interests. Secondly, the patient's right to prohibit treatment extends even to lifesaving treatment. The state has no right or power to intervene to protect patients from themselves. ${ }^{5}$ Lord Donaldson M.R. declared in $\operatorname{Re} T: 6$

\footnotetext{
- Professor of Law, University of Manchester.

* Professor of Bioethics and Applied Philosophy, University of Manchester.

The authors gratefully acknowledge the stimulus and support of the Commission of the European Communities (DGXII) Biomedical and Health Research Programme (BIOMED 2).

We would like to thank John Murphy for his constructive and critical comments on an earlier draft of this paper.

' Collins v. Wilcock [1984] 1 W.L.R. 1172 at 1177 per Goff L.J.

2 B1. Comm. 3, Bl. Comm. 120. And see Clerk and Lindsell on Torts (17th edn.) (1995) at para. 12-01.

${ }^{3}$ [1985] A.C. 871 (H.L.). Though note the glimmer of light in Smith v. Tunbridge Wells H.A. [1994] 5 Med. L.R. 334.

4 See Devi v. West Midlands R.H.A. [1980] 7 C.L. 44.

${ }^{3} \operatorname{Re} T$ (Adult: Refusal of Medical Treatment) [1992] 4 All E.R. 649 finally laying to rest the long heresy expounded in Leigh v. Gladstone [1909] 26 T.L.R. 139.

'Ibid., at 661 .
} 
The patient's interest consists of his right to self-determinationhis right to live his own life how he wishes, even if it will damage his health or lead to his premature death. Society's interest is in upholding the concept that all human life is sacred and that it should be preserved if at all possible. It is well established that in the ultimate the right of the individual is paramount.

It is perhaps ironic that when at last English law catches up with ethical debate and confirms the individual's right to control medical treatment, events are forcing ethicists and health professionals to review the relationship between patients' rights and patients' responsibilities, particularly in the context of infectious diseases. ${ }^{7}$ Patient autonomy has more commonly been analyzed by lawyers and philosophers in the context of diseases and conditions which affect that individual patient alone. A woman has a suspicious lump in her breast. What criteria govern the choices which she must make regarding therapy? A Jehovah's Witness traumatically injured in a road accident refuses blood. A person afflicted by multiple disabilities seeks to have all treatment, even feeding, discontinued. The consequences of each potential choice predominantly affect that patient alone. No other person's physical health is endangered by a choice to reject treatment.

Traumatic injury, cancer and the neurological diseases have been viewed as the "plagues" of post-war Europe. The real plagues, communicable diseases, such as cholera, tuberculosis and the plague itself, have receded in public consciousness. Infectious diseases, those which threatened not only the afflicted patient but the community as a whole, were regarded as of minor import. For most people, infectious diseases equated to influenza and the common cold, or childhood diseases, such as measles, mumps and chickenpox. Catching an infectious disease was nasty but not life-threatening. Vaccination programmes expanded to cover an even greater range of childhood diseases. If someone was unlucky enough to contract "something serious", modern antibiotics offered a cure. The spectre of lethal communicable disease ceased to haunt the nations of Western Europe and the draconian public health measures once commonly invoked to control disease were also largely forgotten. Dogs remained subject to quarantine on entry to the United Kingdom. Human quarantine would be regarded as a violation of civil liberties. Public health became an enterprise largely concerned with studying epidemiology, with public education and prevention of disease. Public health did not directly intrude into

\footnotetext{
$7 \mathrm{~J}$. Harris and S. Holm, "Is there a Moral Obligation not to infect others?" (1995) 311
} British Medical Journal 1215. 
private lives. Public health barely features as an issue in "medical law" texts or literature in the United Kingdom. ${ }^{8}$

This paper reviews the legal and moral dilemmas posed for society by infectious disease asking how far society should recognise and enforce an obligation not to expose others to infection. The AIDS pandemic was of course the trigger for a re-evaluation of rights and responsibilities in relation to communicable diseases. ${ }^{9}$ We shall suggest that in some ways AIDS has obscured rather than clarified the debate. HIV is simply one infectious disease among many. Obligations not to transmit disease should not be determined solely in the context of one disease which provokes so much inflammatory opinion, opinion largely generated not by accurate information concerning the virus itself but by its perceived causes and "victims".

\section{THE SPECTRE RETURNS?}

We must, or course, acknowledge that the primary cause of revived concern, and intermittent public panic, about communicable diseases is quite obviously the AIDS/HIV pandemic. For the media at least, privacy and autonomy swiftly ceased to have major significance once public health was endangered. The seropositive health worker, the allegedly irresponsible haemophiliac found their names blazoned across the headlines. Frequent calls were made for transmission of HIV to be made a criminal offence, for "dangerous" patients to be locked up..$^{10}$ In retrospect, the public health brouhaha generated by HIV can be seen as only the tip of the iceberg of a much more profound dilemma for society. HIV is not a particularly effective infectious agent. It can be transmitted only through direct contact with body fluids. Compared to tuberculosis and cholera, for instance, the threat of contracting HIV recedes in significance. That is not to downgrade the threat of HIV, for while it may be relatively difficult to transmit, many millions of people are infected worldwide and the evidence suggests it is almost inevitably, ultimately, lethal.

\footnotetext{
${ }^{8}$ Contrast the lack of relevant British literature with the extensive jurisprudence and scholarly analysis of public health law elegantly and critically reviewed by L.O. Gostin, "The Americans with Disabilities Act and the Corpus of Anti-Discrimination Law. A Force for Change in the Future of Public Health Legislation" in A. Grubb and M. J. Mehlman (eds.), Justice and Health Care: Comparative Perspectives (John Wiley and Sons 1995) at 105-46.

"See, J. Montgomery, "Victims or Threats?-The Framing of HIV" [1990] Vol. XII Liverpool Law Review 25.

${ }^{10}$ See, for example, the publicity surrounding stories that a young Birmingham haemophiliac who was HIV positive had "deliberately" infected several female lovers: (1992) The Independent, 28 June.
} 
What is now clear, however, is that other far more infectious diseases are not solely of historical interest. The incidence of tuberculosis is rising steadily." Patients seropositive for HIV are showing high rates of concurrent TB infection. Such a patient is far more likely to infect others with tuberculosis than HIV. A growing body of evidence also suggests that an increasing number of patients suffering from tuberculosis are resistant to conventional antibiotics. Resistance often arises from earlier failure to complete prescribed courses of treatment. Other infectious diseases, such as diptheria, cholera and typhoid, were never eliminated from the face of the earth. Outbreaks continue to kill thousands of victims in the poorer parts of the world. Increased mobility, and the chaos in parts of the former Communist sector, bring such diseases back to the doorsteps of the European Union.

The rapid growth of air travel, relaxed immigration controls and emerging infections appearing worldwide mean that we must be as aware of the epidemiology of infection in other countries as we are of events in our own "back yard". ${ }^{12}$

Furthermore any belief that science had overcome communicable disease in this country, or in our European neighbours, was always an illusion. HIV is the sexually transmitted disease every schoolboy hears about. For the past forty years the incidence of other sexually transmitted diseases, such as gonorrhoea, chlamydia, and genital herpes, rose steadily. Women in particular suffered permanent damage to their health and fertility. The "minor" infectious diseases remain with us and are not as minor as first appears. Meningitis kills several children each year. Measles still kills. Chickenpox is simply, and literally, an irritation to most children, but an immunocompromised child can die. Elderly people contracting shingles suffer acutely. Rubella, even today, leads to the birth of damaged infants and very many terminations of pregnancy each year.

\section{DRACONIAN LEGISLATION}

The erroneous belief that communicable diseases had lost their power is matched by ignorance of the continuation of draconian legislation to control disease. In 1985 news that a magistrate had ordered the detention in hospital of a man suffering from AIDS was greeted with surprise and outrage. ${ }^{13}$ Democracies do not generally lock up the sick?

\footnotetext{
"See, the WHO report on the escalation in ruberculosis worldwide: (1996) The Guardian, 22 March.

12 See, the Foreword to E. G. Davies et al., Manual of Childhood Infections (British Paediatric Association 1995).

13 "Detaining Patients with AIDS" (1985) 291 British Medical Journal 1102 (Editorial).
} 
The wisdom of coercion in that instance may be questioned. It has never been repeated in relation to patients with HIV or AIDS. Yet there is no doubt that the magistrate acted entirely lawfully.

The Public Health (Control of Diseases) Act 1984 empowers public health officers to act to prevent the spread of disease. The powers conferred by that Act, and the Public Health (Infectious Diseases) Regulations $1988^{14}$ made under it, permit the state to override virtually all individual liberties in the cause of protecting the community. Where a patient is suffering from a notifiable disease (or food poisoning) confidentiality is abrogated. ${ }^{15} \mathrm{~A}$ person knowing that he is suffering from a notifiable disease, or being responsible for a person so suffering, commits a criminal offence if he exposes others to infection in a public place, ${ }^{16}$ or if he continues with a trade, business or occupation where he risks exposing others to infection. ${ }^{17}$ Notifiable diseases specified under the Act are cholera, plague, relapsing fever and typhus. ${ }^{18}$ Other diseases can and are deemed notifiable by regulations made by the Secretary of State for Health or local authorities. ${ }^{19}$ This extended list of notifiable diseases includes polio, meningitis, diphtheria, dysentery, most common childhood diseases, rabies and tuberculosis. Neither HIV or AIDS is a notifiable disease.

The 1984 Act provides that if a person is believed to be suffering from a notifiable disease, or to be a carrier of such a disease, a magistrate may order that he be tested for that disease. ${ }^{20}$ Where a magistrate is satisfied that a patient with a notifiable disease poses a serious risk of infection to others and his circumstances are such that proper precautions to prevent the spread of disease cannot, or are not, being taken he may order his removal to and detention in a designated hospital. ${ }^{21}$ Additional powers are granted to the Secretary of State to make further regulations with a view to the detention of persons with infectious diseases and in particular to police the entry of infected persons at ports and airports. ${ }^{22}$

An individual infected with a communicable disease specified either under the statute itself or the regulations made by the minister thus loses any effective choice in relation to treatment, and, potentially, his/her liberty and his/her privacy. It may well be the case that once

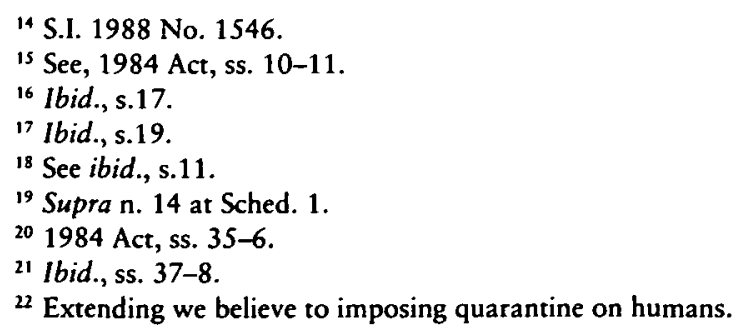


detained in hospital he/she can in theory "choose" not to comply with therapeutic treatment, but that is a pretty empty, futile choice. Failure to protect others from the risk of infection he/she poses, exposes him/her to criminal liability. The cholera sufferer, the victim of tuberculosis, even the patient with scarlet fever (or his/her parents) may face the rigours of the criminal law for dissent from medical advice.

The status of AIDS with this framework of draconian legislation is both interesting and instructive. Neither HIV nor AIDS has been designated a notifiable disease in the United Kingdom. The British Government, and the courts, ${ }^{23}$ have very deliberately decided that guaranteed confidentiality for patients who suspect that they may be seropositive is crucial to any attempt to control HIV. Patients must not be inhibited from seeking testing and counselling. Yet regulations made under the Public Health (Control of Diseases) Act 1984 do extend to persons suffering from "acquired immune deficiency syndrome" the powers to order the removal of a patient to, and her detention in, hospital. ${ }^{24}$ And indeed the power to continue to detain a patient with AIDS in hospital is more extensive than in relation to the other notifiable diseases. Those provisions of the 1984 Act (sections 17 and 19) criminalising conduct exposing others to infection are interestingly not extended to patients with AIDS.

Two features of the public health powers to control AIDS should be noted. First, it seems unlikely that the regulations authorising detention of patients apply to patients with HIV. Only the patient who has developed AIDS is at risk of compulsory "treatment". Secondly, HIV/AIDS finds itself in a half-way house between the coercive powers assumed by the state to control the major communicable diseases and the very different, perhaps more liberal, approach to sexually transmitted disease. The National Health Service (Venereal Diseases) Regulations $1974^{25}$ focus on the creation of a service designed to encourage patients to volunteer for treatment. Confidentiality is strictly enforced and a breach of confidence is justifiable only in the context of contact tracing. No coercive powers to detain patients are provided for, even though most sexually transmitted diseases, unlike AIDS, are readily treatable.

The extent to which the state assumes coercive powers to curtail individual liberty in order to control disease raises deep questions about the extent of personal responsibility and the nature of our harmful contact one with another.

\footnotetext{
${ }^{23}$ See, $X$ v. $Y$ [1988] 2 All E.R. 648.

24 Public Health (Infectious Diseases) Regulations 1988, supra n. 14.

$2 s$ S.I. 1974 No. 29.
} 


\section{DANGER, MORALITY AND RESPONSIBILITY}

As soon as any part of a person's conduct affects prejudicially the interests of others, society has a jurisdiction over it, and the question whether the general welfare will or will not be promoted by interfering with it, becomes open to discussion. ${ }^{26}$

Mill succinctly sums up the fundamental ground on which a democratic society may properly abrogate the autonomy of its individual members. ${ }^{27}$ The range of interests which may be protected against invasion can be the subject of debate. The interest in health and bodily integrity endangered by disease is beyond dispute. The right to life is the core human right. Absent a right to life, all other rights are meaningless. No-one would dispute the right of the state to make laws protecting citizens from violence. The common law, as we have noted, does not differentiate between degrees of violence. We may no more lawfully lightly slap an editor of this Review on the face than we may break his nose. "Trivial" violence is as readily condemned as more obviously injurious conduct for three reasons. First, no contact can be guaranteed as trivial. We may be unaware that the editor has brittlebone disease and our "gentle" slap smashes his cheekbone. Secondly, the provocation offered by the slap may all too readily escalate the level of violence between us. The editor punches John Harris back, blacking his eye. Margaret Brazier responds by breaking a bottle over the editor's head, and so it develops! Violation of an individual's bodily integrity threatens more than the original participants in the incident; it threatens society. Finally, even the gentle "slap" infringes not just the comfort of the victim but his/her essential liberty as well.

Is there any reason to treat disease differently from violence? A slap affronts dignity. A blow may bruise or even break a bone. The hurt will mend. Communicable diseases, to a greater or lesser extent, can kill and inflict irreversible damage to health. HIV is probably lethal in almost all cases. Cholera kills a percentage of its victims. Meningitis kills and leaves others deaf. Sexually transmitted diseases such as chlamydia can destroy a woman's fertility. The interests of others are prejudicially affected by disease to a greater extent than is the case with much of the overt violence which is the everyday business of the criminal law. Nor should the threat to society as a whole posed by disease be lightly discounted. The highly contagious diseases threaten numbers that even the most notorious serial killer could not dream of. Failure by the state to intervene in the face of an epidemic can trigger

\footnotetext{
${ }^{26}$ Essay On Liberty, ch. 1 in M. Warnock (ed.), Utilitarianism (Fontana 1972) at 187-8.

${ }^{27}$ Ibid.
} 
public disorder. Victims of disease may become victims of violence as happened in the recent outbreak of the plague in Southern India.

The danger to society posed by communicable disease is directly analogous to the danger posed by casual violence. But that is not of itself alone sufficient to justify the draconian powers assumed by governments to control such disease. Mill speaks of a "person's conduct prejudicially" affecting others. He does not mandate prior intervention to control such conduct, he merely concludes that that conduct justifies consideration of whether public welfare will be promoted by intervening via coercive measures to curtail the liberty of the perpetrator. ${ }^{28}$ Disease is different from violence in the usual sense of the word. Assuming we are sane, our slapping the editor's face is our voluntary deliberate act. It is truly our conduct which violates his interests. In the majority of instances people do not deliberately and voluntarily spread disease. We may refuse to complete the course of treatment for tuberculosis and by everyday contact infect another twenty colleagues. Unless we deliberately cough in their direction, with express intent to infect a much disliked co-worker, does our conduct directly equate to the deliberate slap?

Perhaps we have conceded too much. While it is true that entering a crowded room knowingly suffering from an infectious disease does not directly equate to the deliberate slap, it may be sufficiently analogous for the moral responsibility for the consequences to be the same. Accepting that in the majority of instances patients do not deliberately and voluntarily spread disease, the crucial question in terms of moral responsibility is what does "deliberately" add to "voluntarily"?

Consider that question in the light of society's experience of HIV/AIDS and the renewed focus that HIV/AIDS offers us on responsibility for communicable diseases. ${ }^{29}$ Suppose a new disease emerges, as did HIV, which, like HIV is untreatable but for which the mode of infection comes to copy another existing infectious disease. To take just one possible scenario, imagine for a moment that this new disease followed the transmission mode of say, pulmonary plague.

Pulmonary plague is an airborne infection with an extremely high transmission rate. Although it is a bacterial infection its mode of infection is paralleled by several viral infections including such common viruses as measles and flu. Anybody present in the same house or flat as a victim of one of these diseases will, at least in principle, be infected. Experimental work shows that the inhalation of one single

\footnotetext{
${ }^{28}$ lbid.

${ }^{29}$ See, J. Harris and S. Holm, "If Only AIDS Were Different" (1993) 26(6) Hastings Center Report 6-13. In this paper a number of different possible disease models for HIV/AIDS are imagined and the moral and social consequences explored.
} 
plague bacterium belonging to one of the more virulent strains is sufficient to cause a potentially lethal infection. Today plague can be treated with antibiotics and the mortality rate for pulmonary plague has dropped from virtually 100 per cent to approximately 10 per cent. Plague is a relatively short-lasting disease both in its pulmonary and its bubonic form so an isolation and quarantine regime is possible, and has been a main feature of the control of plague epidemics since ancient times. ${ }^{30}$

Now suppose the new disease mimicked the transmission mode of pulmonary plague. What would we say of someone who, knowing they were infected and knowing the infectivity and mode of transmission, deliberately went to work? Would we be much impressed by the supposed distinction between deliberately going to work and deliberately infecting another? Or would moral responsibility be attached to voluntarily spreading disease? We are responsible for what we voluntarily bring about, not simply for what we intend, desire or wish to achieve. ${ }^{31}$

Consider society's attitude to drunken driving. The individual who drives with a massive excess of alcohol is held responsible for the harm he causes in an alcohol related accident. That he voluntarily placed others at risk by driving whilst inebriated is sufficient, it need not be demonstrated that he wanted or intended to run down the children in the bus queue. Whether and to what extent we also hold him criminally responsible is of course a further and separate question and one, the answer to which turns on our social policy concerns and to a lesser extent on our theory of punishment. However, the law does frequently punish drunken drivers and so might for related reasons choose to punish those knowingly or recklessly transmitting infectious diseases.

\section{CRIMINAL RESPONSIBILITY}

The means chosen by society to control violence predominantly revolve around the imposition of criminal responsibility. The criminal law acts retrospectively, and focuses on deliberate conduct in the main. We will be punished if we slap the editor. We will not (once again on the fragile assumption we are both sane) be locked up because we might slap him. We will be punished, if we acted deliber-

\footnotetext{
${ }^{30} \mathrm{Ibid}$.

${ }^{31}$ See, J. Harris, Violence and Responsibility (Routledge \& Kegan Paul 1980) and J. Harris three essays on euthanasia: "Euthanasia and the Value of Life"; "The Philosophical Case Against the Philosophical Case Against Euthanasia", and "Final Thought on Final Acts". Each essay is the subject of a response by John Finnis and all are published in J. Keown (ed.), Euthanasia Examined: Ethical Clinical and Legal Perspectives (Cambridge University Press 1995) at 6-22, 36-45 and 56-61.
} 
ately not if we fall against him after too many whiskies at a Christmas party. If we hurt him by negligence, our liberty will not be curtailed, our pockets may be. Responsibility will be normally enforced by the civil not the criminal law.

Control of communicable disease by coercive and anticipatory action within the current legislation on control of disease forces us to ask: why not more readily rely on the criminal law to enforce individual responsibility, buttressed where required by civil law? How can you justify "punishing" non-deliberate conduct-locking up the sick? And most importantly is the public welfare promoted by coercive measures to control disease?

The role of the criminal law in the control of communicable disease is complex. ${ }^{32}$ Disentangling fundamental questions of ethics and policy from practical difficulty is especially problematic. The common law of England founds its prohibition of personal violence on the concept of assault. Any direct physical contact imposed by A on B constitutes common assault. The Offences Against the Person Act 1861 grades assaults, and fixes punishment, by reference to the degree of harm ensuing from that original assault. So a blow inflicting bruising constitutes assault occasioning actual bodily harm, a stabbing provoking a haemorrhage amounts to causing grievous bodily harm. If there is no contact there is no assault. Breathing tuberculosis laden bacteria in the vicinity of a crowded room of vulnerable elderly people, lending a hated colleague an infected handkerchief is unlikely to constitute assault however evil the motive. ${ }^{33}$

The law's concept of contact remains crude and implausible. There is no doubt that a virus is a physical thing and that it can be projected towards others by many means, including nasally or orally projected airborne droplets, and for that matter, within a poison dart or riding piggy back astride a bullet or a discharge of semen. And, having been projected a virus may also, and non-figuratively, strike home, make palpable physical contact, sometimes with deadly effect. If a would-be murderer chooses a fine aerosol spray laden with cyanide gas, he has not renounced offensive weaponry, nor, if the gas reaches its victim, has he failed to make physical contact. Of course, if someone, knowing that they were infected with the pulmonary plague-mimicking new disease that we imagined above, were to enter a crowded bus they might not intend in some narrow sense to infect the other occupants, but they would share the same responsibility for subsequent deaths

${ }^{32}$ See generally, S. Bronitt, "Spreading Disease and the Criminal Law" [1994] Crim. L.R. 21.

${ }^{33}$ Though it would fall within the Law Commission's proposed offence of "causing injury" discussed infra at 191. 
that would fall to the person who entered such a bus firing randomly a machine gun without taking aim at any particular individual or caring whether anyone or no-one was actually hit.

Much ink has been spent on the criminal law and transmission of HIV. If HIV is transmitted via sexual intercourse, there will of necessity be physical contact. So if a seropositive man fails to warn his female partner of his status deliberately planning to infect her, is her consent to intercourse vitiated, rendering what is done to her an assault, if not rape? The balance of authority in England suggests not. ${ }^{34} \mathrm{Her}$ consent to the act of intercourse holds good despite her lack of knowledge of the risks attached to intercourse with that man. Suggestions are made that an alternative offence under the Offences Against the Person Act 1861 may be committed, unlawfully administering a noxious thing, i.e. infection. ${ }^{35}$

We do not propose to explore further the niceties of law of assault and analogous crimes. ${ }^{36}$ No doubt elegant arguments can be formulated to force transmission of disease into the straitjacket of assault or related criminal offences. In practical terms an approach to criminal responsibility and disease founded on the concept of assault is fundamentally flawed. Actual physical contact is irrelevant. The hurt inflicted by disease is not dependent on such conduct. The crimes of assault very necessarily in their proper sphere require that the accuser prove the accused inflicted the harm of which he/she complains. It would be unjust for John Harris to be punished for blacking the editor's eye if it could not be proved that he, and not the editor's disgruntled wife, inflicted the relevant actual bodily harm. Requirements of proof of causation satisfy the needs of justice and are generally pragmatically possible. Proof (whether beyond reasonable doubt or on the balance of probabilities) that $\mathrm{X}$ infected $\mathrm{Y}$ is much more problematic. The man charged with infecting his lover with HIV will cite her promiscuity as evidence that another was responsible. The parents who believe that their child was infected with tuberculosis by a reckless patient defying medical advice may never be able to prove their hypothesis. True, these are evidential problems which may be contingent upon particular difficulties of identifying say viral strains. In the relatively near future we may be able to track specific vira and establish the source, albeit at considerable cost. We should not, however, in any event establish principles which are hostage to contingent practical problems.

\footnotetext{
${ }^{34}$ R. v. Clarence (1888) 22 Q.B.D. 23; discussed in R. v. Lineaker [1995] Q.B. 250 at 258-61 and see, Hegarty v. Shine (1878) 4 L.R. Ir. 288.

${ }^{35}$ See, ss. 23, 24.

${ }^{36}$ They are elegantly reviewed by Bronitt, supra $\mathrm{n} .32$.
} 
If the criminal law is to play an effective role in the control of disease, the law should seek to punish an offender's fundamental irresponsibility rather than focus exclusively on the outcome of such irresponsibility. Society's interest is in deterring the infected and infectious from creating unjustifiable risks to others.

Arthur Miller's play All My Sons illustrates poignantly this very point. The Keller family and in particular Steve Keller, who does not appear in the play, were responsible for manufacturing and shipping defective cylinder heads for aircraft in the second world war. Joe Keller admits his part in the killings: "I was the beast; the guy who sold cracked cylinder heads to the Army Air Force; the guy who made twenty-one P-40's crash in Australia". But he does not feel himself to be guilty because he pulled no trigger, he only failed to go to work on the relevant day and stop the shipment and thereafter he kept quiet, although he could have recalled the engines. As he says of Steve Keller his "partner in crime": "I know he meant no harm". Neither of them intended or planned the deaths of those pilots. But such excuses do not wash with the next generation of the family. As Ann Keller says of her father "He knowingly shipped out parts that would crash an airplane" and her brother Chris says bluntly "He murdered twentyone pilots" ${ }^{37}$ The crucial issue is not what we directly intend but what we knowingly and voluntarily bring about. ${ }^{38}$ This is what makes Steve and Joe Keller murderers in the eyes of their family and in the eyes of every audience. They recklessly and voluntarily endangered the lives of others and their act was complete when the parts were shipped and not recalled before the planes flew.

At the end of the play Joe Keller discovers that his own son, Larry, also a pilot in the war, had committed suicide when he learned of the family complicity in murder. Trying to make Joe and his mother take responsibility, Larry's brother Chris repeats his indictment of his father "Larry didn't kill himself to make you and Dad sorry" and his mother responds "What more can we be?". Chris's answer carries the message of the play: "You can be better. Once and for all you can know that there is a universe of people outside and you're responsible to it, and unless you know that, you threw away your son, because that's why he died". ${ }^{39}$

Interestingly, although the play is concerned to make key characters and its audience face up to their personal responsibilities, it assumes that there will be criminal responsibility for such conduct. Steve is in prison for his part in the deaths. And whether or not imprisonment is

\footnotetext{
${ }^{37}$ A. Miller, All My Sons (Penguin 1961) Acr One (p. 117).

${ }^{38}$ See, J. Harris, Violence and Responsibility (Routledge and Kegan Paul 1980).

${ }^{39}$ Miller, supra n. 37 at Act Three (p. 170).
} 
appropriate, the point about social as well as personal responsibility for reckless endangerment is well taken. In terms of their moral responsibility it does not matter whether or not a particular defective engine caused a crash. The reckless endangerment is what we all have a moral responsibility to prevent and there is clearly a strong public interest in controlling reckless endangerment.

In Scotland the recognition of reckless endangerment as a criminal offence enforces such a policy. ${ }^{40}$ In England a patient suffering from certain notifiable diseases may commit an offence under the Public Health (Control of Diseases) Act 1984 if he exposes others to the risk of infection in a public place. That prosecution is a practical reality, and not simply a theoretical possibility, was illustrated in 1994 in $R$. v. Gaud. ${ }^{41}$ A surgeon suffering from Hepatitis B defied the advice of the General Medical Council and continued to practise. He took measures to evade screening for the disease including substituting patient's blood for his own. It was suspected, but could not be proven, that he had infected patients. He was convicted of causing a public nuisance and gaoled for a year. ${ }^{42}$ If the will is present, the means can be found to punish those who spread disease. The common law may not always be logical, but innovative judicial action can often render it flexible..$^{43}$ But should we seek to do so? ${ }^{44}$

The arguments for and against the use of the criminal law to promote responsible behaviour by those who risk exposing others to infectious disease are finely balanced. Behaviour such as that of $\mathrm{Dr}$ Gaud cannot be distinguished from that, say, of a train driver who consumes several whiskies before embarking on driving an Inter-City express. Few would doubt that he should be punished regardless of whether his inebriated state results in disaster or not. If a seropositive person deliberately embarks on a campaign to infect others, concealing his condition from his several partners, and practising the very opposite of safer sex, his conduct is morally analogous to that of the conventional serial killer. If individuals who endanger others by

${ }^{40}$ See generally, J. K. Mason and A. McCall Smith, Law and Medical Ethics (4th edn.) (Butterworths 1994) at 48-9; G. T. Laurie, "AIDS and Criminal Liability under Scottish Law" (1991) 36 Law Society Scotland 312.

4 See, M. Mullholland, "Public Nuisance-a New Use for an Old Tool" (1995) 11 Professional Negligence 70.

${ }^{42}$ In an analogous case in Canada an HIV positive blood donor was convicted of commirting a public nuisance: $R$. v. Thornton [1993] S.C.R. 445; a similar prosecution grounded on infection of sexual partners failed: $R$. v. Ssenyonga (1992) 73 C.C.C. 3d 216 (other criminal charges were proceeding).

${ }^{43}$ See, U.S. v. Joseph (1993) 37 M.J. 392 noted in (1994) 2 Med. L. Rev. 244 (AG).

4 For a resounding no, to this question see A. Grubb, commentary to U.S. v. Joseph; ibid 43 at 251 . 
reckless or deliberate behaviour ought to be accountable to society for what they do, disease, unless it has so distorted judgement to raise questions about the accused's sanity, does not exempt the wrongdoer from the general rule.

However no empirical evidence has suggested other than that the numbers of infected persons who endanger others out of malice or wilful disregard for others are tiny. The number of successful criminal convictions will be low. The role of the criminal law will be largely symbolic. And the symbolism may not be entirely beneficial. ${ }^{45}$ The law may prescribe that only the healthworker who quite deliberately conceals her health status and knowingly endangers her patients commits a criminal offence. The law may provide that only on proof that an HIV positive Lothario who deliberately risks infecting his several partners, shall he be punished. Nonetheless, the public may come to perceive that any transmission of disease, or at least of HIV, is criminal. Patients suffering from infectious disease will be stigmatised as potential criminals. Such a stigma will deter them from volunteering for screening and treatment.

At a practical level too the role the criminal law can play in control of communicable diseases will be perceived as likely to be minimal. The criminal law operates retrospectively. Its deterrent and protective impact depends on the existence of laws and the possibility of punishment re-inforcing individuals' sense of social responsibility. It cannot be an effective means of controlling a true epidemic. The pre-eminence given in public health laws to measures to restrain infected persons from contact with others, and the relatively low value attached to criminal sanctions, testifies to this fact. Restraining those who pose a real risk to life and health, regardless of their motives or lack thereof, may be seen as a much more pragmatic policy. But can such a crude violation of autonomy be justified?

\section{RESTRAINING THE DANGEROUS}

The Public Health (Control of Diseases) Act 1984 in conferring powers to remove persons suffering from certain infectious diseases (including AIDS) to hospital does not address the intent or state of mind of the patient. If there is a serious risk of infection to others and proper precautions cannot be taken to prevent the spread of infection outside hospital, off to a designated hospital the patient may be sent. The patient with, for example, tuberculosis may be too ill to appreci-

\footnotetext{
4s See, for example, R. Porter, "History Says No to the Policeman's Response to AIDS" (1986) 293 British Medical Journal 1589;. P. Old and J. Montgomery, "Law, Coercion and Public Health" (1992) 304 British Medical Joumal 891.
} 
ate risk to others. The patient with typhus may be a Christian Scientist who scorns the notion of illness. Both may be exemplary characters with no design to harm others. Yet on objective evidence that they might cause harm, and without the protection of the criminal process, they can lose their liberty. Of course they are not alone in facing loss of liberty without proof of crime. The mentally ill patient can be confined to protect others. Tom Campbell and Christopher Heginbotham ${ }^{46}$ have attacked such discrimination against mental illness arguing:

In particular, discrimination occurs when dangerous persons who are not suffering from mental illness are not detained on protectionist grounds although their dangerousness is of a type and degree which would make them liable to detention if they were diagnosed as having a mental illness ...

Patients suffering from certain dangerous communicable diseases are, however, susceptible to detention on just such protectionist grounds. A small sub-category of victims of physical illness find themselves in just the same case as the mentally ill. Are both groups wrongfully deprived of liberty and autonomy?

David Price ${ }^{47}$ reviews the arguments for some form of preventive civil detention of those dangerous to others which might include the "critically infectious individual" even though he was not engaged in intentional, reckless or even negligent conduct. The state is entitled to intervene to protect citizens from physical harm.

The implementation and content of powers of civil detention nonetheless concern him. In the context of mental illness Price is concerned to distinguish between compulsory detention to treat patients whose disorder is treatable and who are incapable of making autonomous choices for themselves, and those who retain the capacity to make an independent judgement, whose condition may be untreatable, but who nonetheless pose a danger to other. He stresses the primary importance of devising a system for what he describes as "police-powers" to detain the latter category of persons which conform to strict criteria of natural justice. He canvasses how far such "police-powers" can or should be largely incorporated in the criminal justice system. Above all, he rejects a "medical model" of decisionmaking in relation to mentally ill persons removed from society to protect others. Doctors' business is to treat the sick not to safeguard society. Doctors may generally only treat the sick who want treatment, or whose illness has rendered them incapable of independent judgement.

\footnotetext{
${ }^{46}$ In Mental Illness, Prejudice, Discrimination and the Law (Dartmouth 1991) at 98.

${ }^{47}$ D.P.T. Price, "Civil Commitment of the Mentally III" (1994) 2 Med. L. Rev. 321 at 347.
} 
Much of Price's argument is difficult to refute, nor would we wish to do so. Liberal democratic societies restrain dangerous conduct by punishing acts endangering others' safety. Individual responsibility is enforced through the deterrent impact on the criminal and civil law. The state intervenes to condemn what people do not what they are. Intervention to curtail liberty or autonomy prior to any dangerous tendency manifesting itself in dangerous action needs exceptional justification. If such justification is grounded on disease there are no sound grounds to discriminate between mental and physical illness. What is necessary is to delve further into reasons why risks triggered by disease differ from risks triggered by bad temper, unsocial living conditions or over-indulgence in alcohol, all of which remain exclusively the concern of the criminal justice system operating retrospectively.

Two possible reasons for treating communicable diseases differently suggest themselves. Neither is entirely convincing. First, the relevant disease, physical or mental, may be perceived as so radically increasing the risk that the inherent danger it poses to others will manifest itself in tangible harm to those others that the case is readily distinguishable from other "dangerous tendencies". If $\mathrm{X}$ has pulmonary plague and does not submit to isolation he will infect virtually everyone he comes into contact with. The likelihood of even the most violent alcoholic attacking more than one or two people a day is low. Secondly, disease may distort judgement and diminish individual responsibility. ${ }^{48}$ Laid low with cholera, Y may no longer appreciate basic requirements of hygiene or be able to assess the danger her habits pose to the rest of her household. She is not deserving of punishment. Deterrence can not affect actions which her disease disables her from understanding. Such arguments are analogous to arguments which can be applied to certain sorts of mental disorder. The patient's illness may increase the risk of dangerous conduct harming others and may distort her judgement in relation to the interests of others.

The difficulty with both arguments in the context of communicable diseases is that neither can be applied universally to physical ills any more than mental disorder. Communicable diseases vary widely in their degrees of infectivity and of course in their mode of transmission. ${ }^{49}$ It is by no means the case that judgement will always be distorted by such disease thus diminishing personal responsibility. Pulmonary plague, cholera, typhus and meningitis clearly meet both

\footnotetext{
${ }^{48}$ Justifying the coercive powers enabling the state to detain mentally ill patients, Sir Thomas Bingham M.R. said: "..the very illness which is the cause of danger may deprive the sufferer of the insight necessary to ensure access to proper medical care...": In re S-C (Mental Patient: Habeas Corpus) [1996] 2 W.L.R. 146 at 148.

49 See, L. Gostin, infra n. 61 at 130-9.
} 
tests. They create exceptional risk to others and may temporarily disable the patient from exercising responsibility for himself or others. ${ }^{50}$ Tuberculosis creates a high risk of infection but will not necessarily distort judgement at the same point in time. HIV and Hepatitis $B$ and $C$ are even more problematic. Infectivity rates are much lower and infection will not be transmitted without some deliberate act on the part of the infected person. Judgement will not be impaired. Similarly persons who are carriers of communicable disease, but suffer no symptoms of disease pose problems for society. Such persons remain capable of making decisions for themselves about the risk they pose to others if they are aware that they are carriers. Is there any better reason to act against such persons prior to establishing that they have committed irresponsible and dangerous acts than to act against the woman of known violent temper? We suggest that there may not be. Yet any recklessly endangering behaviour of the individual who knows that he/she may endanger others by transmitting a disease that can kill or permanently impair others' health is no less morally wrong than that of his/her sister who makes no effort to curb her odious temper. Must we return to the thorny issue of criminal responsibility once again?

\section{CRIMINAL RESPONSIBILITY AGAIN?}

Anticipatory intervention to restrain those rendered dangerous by disease requires evidence of the exceptional degree of that danger and of at least some impairment of the individual's ability to exercise personal responsibility for others' safety. Conduct which deliberately or recklessly endangers others is the proper province of the criminal justice system. It is a conclusion we arrive at with some reluctance accepting the concerns expressed earlier about both the practical utility of the criminal law in this context and the symbolic danger of stigmatising disease.

Consider again the case of Dr Gaud. ${ }^{\text {s1 }}$ Could it have been just to

\footnotetext{
${ }^{s 0}$ Moreover if the disease renders the patient temporarily "incompetent" he/she can presumably be treated once settled into hospital under the "best interests" doctrine enunciated in $F$ v. West Berkshire H.A. [1989] 2 All E.R. 545 (H.L.). Note that the Law Commission expressly acknowledges that mental incapacity may be triggered by physical disease; see Law Commission Report No. 23, Mental Incapacity (1995) at paras. 3.11-3.13. Being able to treat the patient detained overcomes one of the fundamental objections to the current powers of detention in the Public Health (Control of Diseases) Act 1984 that the Act violates civil liberties "without any saving therapeutic benefit"; see I. Kennedy and A. Grubb, Medical Law: Text with Materials (2nd edn.) (Butterworths 1994) at 83-4.

s1 See, supra at 83.
} 
allow his irresponsible conduct to go unpunished? Yet could anticipatory action to restrain his "dangerous tendency" have been justified? Had evidence emerged earlier of his status as a Hepatitis B carrier would anyone seriously contend that his liberty could properly have been curtailed because of evidence his character was such he might proceed to evade all restrictions on his medical practice and thus endanger patients? Would any rational individual argue that all persons suffering from tuberculosis should be subjected to coercive treatment? Only the most irrational bigot has ever suggested persons with HIV should be subjected to enforced celibacy. In each of these examples the infected individual in question only endangers others if he deliberately acts in a manner calculated to endanger others without regard to their interests or safety. Until he has so acted anticipatory constraint is no more justifiable than in the case of those with other dangerous tendencies. If he does so act, his conduct is equally deserving of punishment as the woman who allows her temper to cause her to lash out at her neighbour, or the driver who permits his fondness for wine to cause him to endanger other road users by driving under the influence of alcohol.

It may be argued that we have concentrated too much of our argument on Dr Gaud. His is an exceptional case in two senses. There is no evidence that other health professionals have acted with similar gross disregard of their patients' welfare. And, infected professionals are themselves an exceptional category of infected, and infectious individuals. Their patients are entirely "at their mercy" unable to protect themselves from the risk posed to them by the doctor or nurse. In society more generally the uninfected person has the ability and the obligation to protect himself. The argument is most often advanced in relation to HIV. The risks of unprotected sexual intercourse are known to all. The primary responsibility to prevent transmission of HIV is to protect oneself by insisting on condom use, a discriminating choice of partners and undertaking cross-examination of such partners about their sexual history before embarking on sexual intercourse. Yet condoms only decrease the risk of transmission of HIV, partners may lie, and equality of bargaining power is not always present between partners. Is a person who deliberately conceals his HIV status, who rejects use of a condom, and adopts a "what the hell" approach to his lover's safety any less morally culpable than Dr Gaud? Outside the context of HIV, can those threatened by other disease protect themselves any more effectively than Dr Gaud's unfortunate patients? How is the passenger on the Manchester to Euston express to know that the woman in the next seat has tuberculosis rather than just a very bad cold?

We are not arguing that it should be a crime to transmit disease only that conduct which quite calculatedly exhibits total disregard for 
others' health and safety falls within the ambit of criminal law. The essence of the wrong committed by the individual who deliberately exposes others to disease is that of recklessly endangering others. The fact that either no-one else has actually been harmed by contracting the relevant disease, or that it cannot easily be proved that transmission of disease resulted from the accused's reckless conduct should not be relevant. Reckless endangerment should be recognised in its own right as a substantive criminal offence and one well suited, but not confined to, imposing responsibility to transmission of disease.

\section{REFORMING PUBLIC HEALTH LAWS}

We have sought to demonstrate that in an appropriate case even draconian limitations on autonomy imposed by public health laws to control transmission of communicable diseases are justifiable in principle. There is as strong a moral responsibility to protect others from contracting disease as there is to safeguard them from any other violation of bodily integrity. Translating that responsibility into legal principle is more awkward. The current legislation, the Public Health (Control of Diseases) Act 1984 and the 1988 Regulations, ${ }^{52}$ go only part of the way to an acceptable solution. The legislation has become to some extent antiquated. Its language is more reminiscent of the Victorian era than our own. ${ }^{53}$ In so far as questions of criminal responsibility are pertinent any reform of the law relating to transmission of disease must take account of the Law Commission's proposals for introducing a Criminal Code. ${ }^{54}$ Four particular issues need to be addressed:

"[N]o adult citizen of the United Kingdom is liable to be confined in any institution against his will, save by the authority of law."

The Master of the Rolls asserted that fundamental principle when construing the provisions of the Mental Health Act 1983 in In re S-C (Mental Patient: Habeas Corpus).ss Moreover he made it clear that in relation to the detention of the mentally ill, substantive justice must be done and be seen to be done. The state can justify violating the liberty and autonomy of the sick patient, but the process achieving that result must be fair and just. The health care practitioners cannot just "lock up" those perceived to be a danger or a nuisance.

\footnotetext{
s2 See, supra n. 14.

${ }^{53}$ For parallels with the USA, see again, L. Gostin, infra n. 61 at 105.

54 Law Commission Report No. 177, A Criminal Code for England and Wales (H.M.S.O. 1989); Law Commission Report No. 218, Legislating the Criminal Code: Offences Against the Person and General Principles (Cmnd. 2370 H.M.S.O. 1993).

ss [1996] 2 W.L.R. 146 at 148.
} 
The provisions in sections 35 to 38 relating to medical examination of carriers and detention of sufferers grant extensive, and ex parte, powers to magistrates. Theoretically the safeguard of a "legal model" for compulsory intervention against a person's will is thus provided offering, some might contend, better protection than the "medical model" predominant in the Mental Health Act 1983. Realistically a "medical model" is likely to operate with magistrates relying heavily on certificates and evidence offered by doctors. The physically ill, "critically infectious individual", is offered less by way of due process to protect his/her interests than his/her mentally ill sister. The safeguards and procedure, built into the overtly "medical model" of the Mental Health Act 1983 are absent. No review process akin to that provided by Mental Health Review Tribunals exists. Of course, in the context of communicable disease time will be of the essence. There is little utility in a three day hearing in the course of which perhaps many others become infected. However, given the number of circuit judges now available across the jurisdiction, a more senior and experienced judge should be empowered to hear any application for intervention and provisions built into the legislation for review of initial emergency judgments.

(2) The classification of diseases as properly subjects of anticipatory action must be reviewed. ${ }^{56}$ The principles we suggest above should govern the legitimacy of imposing any prior restraint on the liberty or autonomy of victims or carriers of disease. There must be evidence that the risk of transmission of disease is exceptionally high and that that disease impairs the individual's judgement and diminishes his responsibility and ability to safeguard others from the danger he presents to them.

(3) Those who endanger others by means of reckless conduct risking transmission of disease should be dealt with by the criminal law. Section 17 of the Public Health (Control of Diseases) Act 1984 already creates a limited offence of exposing others to infection but its remit is limited to notifiable diseases and exposure in public places. Neither limitation is rational. Violence in private is not (at least in principle) treated differently from violence in public nor should disease so be. The core of the wrong done by a person recklessly exposing another to disease is unrelated to the disease.

(4) Such general statements of principle are however much simpler to enunciate than to implement. Consideration needs to be given to whether criminal responsibility for transmission of disease should be embraced within the general criminal law or made the subject of a

${ }^{s_{6}}$ Our conclusion on classification of disease reflects those of L. Gostin, infra n. 61 reviewing analogous US legislation. 
specific "public health" offence. The Law Commission in its proposals for wholesale reform of the criminal law in England barely touched on responsibility for transmitting disease. In a brief reference to disease, it is baldly stated that the proposed new offence of intentionally or recklessly causing injury to another is broad enough to include inflicting illness or disease on another. ${ }^{57}$ That statement leaves several issues unresolved. Problems of proof of causation remain. The law can intervene only once the accused's reckless conduct has resulted in injury. Had Dr Gaud been discovered to be endangering patients earlier, his reckless conduct of itself would not be caught by an offence of causing injury. No threshold is set in terms of the nature of diseases triggering criminal liability. ${ }^{58}$ The issue of consent is unaddressed. Inflicting more than transient injury remains a criminal offence in England regardless of consent. ${ }^{59}$ Whatever the rights and wrongs of such policy in other contexts ${ }^{60}$ disregarding consent in the context of sexually transmitted disease would be a nonsense. The wrong is not the transmission of disease per se but the violation of the other person's right to control over his/her own body and health.

Our personal preference remains in principle that reckless transmission of disease should be regarded as part and parcel of a wider wrong of recklessly endangering others' safety. We see no moral grounds to distinguish Dr Gaud from the drunken train driver or the employer who flouts health and safety law, in disregard of his workers' safety. Such an approach would meet part of the case against stigmatising disease. The seropositive person who conceals that he is HIV positive from several lovers with whom he engages in unprotected sex is not punished for being HIV positive, nor singled out for unfair treatment. $\mathrm{He}$ is punished for his conduct not for his health status. Disease should never result in unjust stigma, but nor, as long as it does not impair a person's mental capacity, should it confer special privileges immunising the individual from responsibility to others.

However we acknowledge that in the absence of support from the Law Commission for such a broad, general offence of "reckless endangerment", the best prospect for reform lies in urgent and radical amendment of the Public Health (Control of Diseases) Act 1984. That course has advantages to recommend it too. Reform of the Act must aim to ensure that a rational pattern of principles can be developed

57 Law Commission Consultation Paper No. 122, at para. 8.17.

${ }^{58}$ Perhaps no threshold should be set? Passing on a cold may generally be of trivial import but could be fatal to an immunocompromised patient: see S. Bronitt, supra $\mathrm{n}$. 32 at 28 ; and see J. Harris and S. Holm, supra n. 29.

s9 R. v. Brown [1993] 2 W.L.R. 556 (H.L.); see S. Bronirt, supra n. 32 at 30-2.

${ }^{50}$ On which see, Law Commission Consultation Paper No. 139, Consent in the Criminal Law (H.M.S.O. 1995). 
governing both imposing prior restraints on liberty and autonomy and creating criminal responsibility for conduct placing others at risk of disease. It will require that legislators and policy-makers at last address how a modern society can reconcile the right and responsibilities of those who contract communicable diseases, and those who are at risk of so doing. It is an enterprise long overdue and needs to be embarked on, not as a panic response to a new epidemic, nor as a knee jerk response to HIV but in a calm, deliberate manner to anticipate the difficulties that the return of the "real" plagues may pose.

Public health laws in the United Kingdom have attracted little scholarly attention from "medical lawyers" as yet. In comparison with their counterparts in the United States of America, British public health officials have generally eschewed resort to the law. Writing from the USA Larry Gostin ${ }^{61}$ invokes the provisions of the Americans with Disabilities Act $^{62}$ to argue forcefully for reform of public health law to eliminate unjust discrimination against persons suffering from communicable disease. Our conclusion that the criminal process does have a role to play in the control of communicable disease may at first sight diametrically opposed to Gostin's thesis, re-enforcing discrimination on grounds of disease status. The conflict is much more apparent than real, a matter of language not substance. Gostin acknowledges the right of the state to act to protect its citizens from disease. We endorse the right to be protected from unjust discrimination. What we seek to achieve are laws which strike the proper balance between rights and responsibilities in the context of communicable disease, and which offer all those whose rights are endangered either by violation of their liberty or by a threat to their health, an adequate legal process to protect such rights.

${ }^{61}$ See, "The Americans with Disabilities Act and the Corpus of Anti-Discrimination Law: A Force for Change in the Future of Public Health Regulation" in A. Grubb and M. J. Mehlman (eds.), Justice and Health Care: Comparative Perspectives supra, n. 8 at $105-46$.

${ }^{62}$ The Disability Discrimination Act 1995 includes specifically within its provisions HIV (see s. 1(1) and Sched. 1(8)), although it is not at all clear whether any protection is offered to the seropositive individual who remains asymptomatic: see ibid., Sched. I(4). Other communicable diseases will only even arguably fall within the Act where their effect results in a long term impairment of health (at least 12 months). More importantly even if a patient suffering from such a disease can claim the protection from discrimination afforded by the Act against, for example, employees or education providers, nothing in the Act affects or can affect the state's powers in the Public Health (Control of Diseases) Act 1984 and Regulations. Thus, unlike Gostin, (see, supra n. 61) we cannot (at least yet) use anti-discrimination law to prompt the Government into the review we seek in order to implement modern, realistic public health provisions. 